\title{
Is there temporal variation on solid waste stranding in mangroves? A case study in Ratones mangrove, Florianopolis, Brazil
}

\author{
Bianca Pinto Vieira * \\ Dayse Dias \\ Elaine Mitie Nakamura \\ Tammy Iwasa Arai \\ Natalia Hanazaki \\ Universidade Federal de Santa Catarina, Departmento de Ecologia e Zoologia \\ Laboratório de Ecologia Humana e Etnobotânica \\ Campus Trindade, CEP 88.040-970, Florianopolis, SC - Brazil \\ * Corresponding author \\ biancabioufsc@gmail.com
}

Submetido em 04/06/2012

Aceito para publicação em 11/11/2012

\section{Resumo}

Há variação temporal no encalhe de resíduos sólidos urbanos em manguezais? Um estudo de caso no manguezal de Ratones, Florianópolis, Brasil. Áreas de manguezais estão diminuindo em todo o mundo devido às fortes pressões antrópicas geradas pelo crescimento populacional. Entre as atividades mais danosas, estão aterramentos, carcinicultura e o despejo de resíduos. Quanto aos resíduos sólidos, os estudos de padrões espaciais e temporais de encalhe são necessários para entender sua dinâmica, identificar possíveis fontes de despejo e entender seu papel na dispersão de organismos nas áreas naturais. Neste estudo, foi analisada a variação temporal de encalhe de resíduos sólidos no manguezal de Ratones, noroeste da ilha de Santa Catarina (Brasil), durante um ano. Os resíduos encalhados em oito parcelas de $50 \mathrm{~m}^{2}$ alocadas aleatoriamente foram coletados, quantificados e qualificados in situ mensalmente. Itens de plástico e nylon (ambos derivados de petróleo) representam $80 \%$ dos resíduos encalhados. Houve diferença significativa no encalhe temporal para o plástico, contudo não para o nylon. Os resíduos foram encontrados em todas as amostras e durante todo o ano, sendo algumas áreas mais afetadas. Áreas com densa borda de Spartina alterniflora Loisel (Poaceae) parecem ter menos resíduos no interior do bosque, talvez devido ao efeito de malha destas formações de gramíneas atuando como uma barreira. Os resultados encontrados refletem aspectos preocupantes para conservação, pois este manguezal é constantemente impactado pelo encalhe de resíduos sólidos urbanos, com maior concentração em áreas importantes como berçário.

Palavras-chave: Área Costeira; Contaminação; Ilha de Santa Catarina; Lixo

\section{Abstract}

Mangrove areas are decreasing around the world due to population increase. The most damaging activities include embankments, shrimp farming, and dumping of wastes. The temporal and spatial stranding patterns of 
solid waste are important to establish probable sources and understand their role in the dispersion of organisms through natural areas. In this study, we analyze temporal variation of solid waste stranding in Ratones mangrove, northwestern of Santa Catarina Island (Brazil). Samplings were carried out monthly during one year in four different areas. In each area, two $50 \mathrm{~m}^{2}$ random plots were sampled per month. All solid waste strands on the plots were removed, quantified, and qualified. Plastic and nylon items (both made of petroleum) represented $80 \%$ of waste stranding. There were significant differences in temporal stranding with regard to plastic, but not to nylon. Wastes were found in all samples throughout the year, and some areas are more affected than others. Places with dense edges of Spartina alterniflora Loisel (Poaceae) seem to have less solid waste inside mangrove forest, perhaps due to the effect of grass acting as a mesh barrier. The results reflected concerns with conservation, considering that these coastal ecosystems are impacted by waste dumping throughout the year, with highest concentration within important nursery points.

Key words: Coastal Zone; Contamination; Island of Santa Catarina; Litter

\section{Introduction}

Mangrove forests are very complex, dynamic, highly resilient, and resistant. They are characterized to occur in tropical zones and some subtropical regions all over the world (LUGO; SNEDAKER, 1974; CHAPMAN, 1977; SCHAEFFER-NOVELLI; CIN65*6TRÓN, 1986; SPALDING et al., 1997; LAL, 2003; NAGELKERKEN et al., 2008). Mangrove plant community consists of typical species, which are adapted to high saline substrate and periodical tide flooding (CHAPMAN, 1977; SCHAEFFER-NOVELLI; CINTRÓN, 1986; TOMLINSON, 1988; SPALDING et al., 1997; PARIDA; JHA, 2010). This ecosystem provides breeding, nesting, protection, and feeding to several species (CHAPMAN, 1977; SCHAEFFER-NOVELLI; CINTRÓN, 1986; TOMLINSON, 1988; NAGELKERKEN et al., 2008). Due to its ecological and socioeconomic significance, the Brazilian legislation establishes specific standards to ensure mangroves as permanent preservation areas. However, lack of knowledge about the law among people living nearby mangroves, shortage of resources and staff for environmental inspection agencies, as well as political and economic conflicts constitute strong factors to protection ineffectiveness.

Decrease in mangrove areas around the world is directly related to pressures generated by industrial and urban growth (POLIDORO et al., 2010). Pipeline work, changes in river flows, embankment, shrimp farming, salt extraction, and dumping of wastes are among the most damaging human activities (HAMILTON; SNEDAKER, 1984). The negative impacts of wastes on local fauna includes ingestion (VLIETSTRA; PARGA, 2002; PROVENCHER et al., 2010; TOURINHO et al., 2010; POSSATTO et al., 2011) and entanglement (DERRAIK, 2002), besides dispersion of exotic and invader species (BARNES, 2002; BARNES; MILNER, 2005). Floating anthropogenic objects might facilitate long distance transport of species (THIEL et al., 2011) and result in native diversity loss at new locations (BARNES; MILNER, 2005).

Temporal differences in waste accumulation can be related to many variations, such as periodicity of beach use and rainfall (IVAR DO SUL; COSTA, 2007; PORTZ et al., 2011; TOURINHO; FILMANN, 2011; MACHADO; FILLMANN, 2010; WIDMER; HENNEMANN, 2010; NETO; FONSECA, 2011; VIEIRA et al., 2011). Spatial and temporal patterns of solid waste stranding are significant to establish probable sources and understand their role in dispersion of organisms through natural areas (BARNES; MILNER, 2005; HINOJOSA et al., 2010).

Florianopolis is famous as a tourist city because of its beaches. According to IBGE (2010), this city has 404,224 inhabitants, but it is estimated to increase to almost 1 million during the tourist period. Each month, 766.6 tons of solid wastes are collected with rises to 825.5 tons on summer (COMCAP, 2011). Population explosion on summer without proper infrastructure has tragic consequences for coastal ecosystems.

Although studies about litter on Latin America beaches and the influence of tourism are already well established, they still have to be developed in other marine 
ecosystems (IVAR DO SUL; COSTA, 2007). Researches about urban solid waste in mangroves are very recent and scarce (eg. GREEN; WEBBER, 1996; SOUZA et al., 2008; CORDEIRO; COSTA, 2010; VIEIRA et al., 2011), perhaps because these environments do not have the same aesthetic and economic appeal of beaches (ARAÚJO; COSTA, 2007; IVAR DO SUL; COSTA, 2007; NETO; FONSECA, 2011).

Vieira et al. (2011) discuss about solid waste quantities and homogeneity of stranding in Ratones mangrove and show that there were spatial differences on solid waste stranding. Taking into account the expected population variation due to tourism and the proximity of mangrove to crowded beaches, temporal differences are also expected, with more wastes on spring and summer. Therefore, this study aims to analyze temporal variation of solid waste stranding in a mangrove region of Florianopolis city, Brazil.

\section{Material and Methods}

Florianopolis is located at Santa Catarina Island (Brazil), nearing the southern boundary of mangrove distribution in South America (CHAPMAN, 1977; SCHAEFFER-NOVELLI; CINTRÓN, 1986; SPALDING et al., 1997). Mangrove forests spread in certain areas both along north and south bays, as well as in island and continent. Some of these mangroves are protected areas, such as the Carijós Ecological Station (Figure 1), which aims to protect Ratones and Saco Grande mangroves.

FIGURE 1: Location of sampling areas at Pontal de Jurerê (or Pontal da Daniela), Carijós Ecological Station (black), Santa Catarina Island, Brazil.

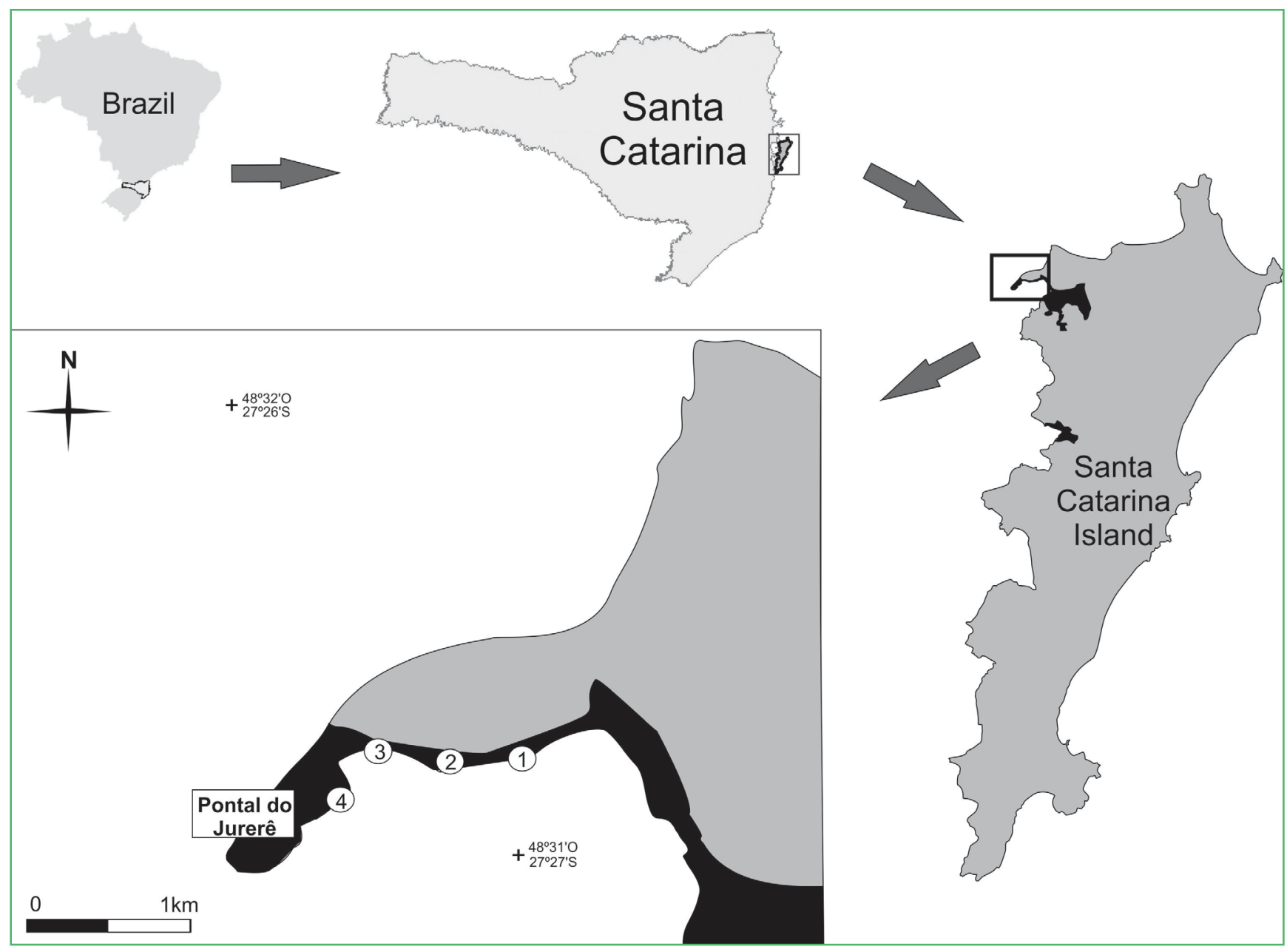


The Ratones mangrove northern limit $\left(27^{\circ} 27^{\prime} \mathrm{S}\right.$ and $48^{\circ} 32^{\prime} \mathrm{W}$ ) is located at the Pontal de Jurerê border (Figure 1), also known as Pontal da Daniela. This formation is a unique transition between mangrove and sandy beach. The mangrove forest is dominated by Laguncularia racemosa (L.) C. F. Gaertn(Combretaceae), Avicennia schaueriana Stapf \& Leechm. ex Moldenke (Acanthaceae) and Spartina alterniflora Loisel (Poaceae), with few individuals of Rhizophora mangle L. (Rhizophoraceae).

At this region, four $650 \mathrm{~m}^{2}$ areas (Figure 1) were chosen (described by VIEIRA et al., 2011) and totally cleaned before the research started, in order to avoid the influence of antecedent debris. Thereafter, two random $50 \mathrm{~m}^{2}$ plots were monthly sampled in each area. This study is limited with regard to seasonal analysis, because using months as sampling periods can lead to a seasonal pseudoreplication (HULBERT, 1984) when only one year is taken into account. Nevertheless, temporal variations were focused throughout one year, with samplings between October 2008 and October
2009 during the lowest tide of each month. All solid waste items were analyzed, regardless of being whole or fragmented. These items were removed from samples and given to the company responsible by solid waste management (Companhia de Melhoramentos da Capital - COMCAP) aiming at a correct destination and to avoid interference by double-counting. Quantifying and qualifying processes happened in situ. Debris were not weighted due to their different nature.

Solid waste was categorized as: plastic, nylon, rubber, metal, wood, glass, tissue, ceramic, and other. Data was transformed to $\log _{2}$ and tested for normal distribution with Shapiro-Wilk test. To test for variance homoscedasticity, Levene's test was used. The temporal variation of solid waste stranding was compared through two-way ANOVA test $(\alpha=0.05)$ using the software Statistica 7.0 (STATSOFT, 2004) and grouping months into seasons (summer: December to February; autumn: March to May; winter: June to August; and spring: September to November). For significant differences, Tukey test post hoc was applied (ZAR, 1999).

FIGURE 2: Percentage of solid waste during seasons between 2008 and 2009 at the Ratones mangrove, Brazil.

\begin{tabular}{|c|c|c|c|c|c|c|}
\hline $100 \%$ & & rim & & & 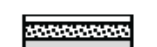 & \\
\hline $90 \%$ & & & 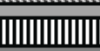 & & 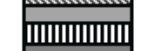 & \\
\hline $80 \%$ & & & & & & \\
\hline $70 \%$ & & & & & & $\square$ Glass \\
\hline $60 \%$ & & & & & & $\mathbb{\mathbb { N }}$ Tissue \\
\hline $50 \%$ & & & & & & $\square$ Ceramic \\
\hline $40 \%$ & & & & & & 四 Rubber \\
\hline $30 \%$ & & & & & & $\square$ Wood \\
\hline $20 \%$ & & & & & & Ⓝvlon \\
\hline $10 \%$ & & & & & & \\
\hline & Spring & Summer & Fall & Winter & TOTAL & \\
\hline
\end{tabular}




\section{Results}

Out of all components collected $(n=602)$ during 12 months, plastic represented the highest percentage of standing $(63 \%)$, followed by nylon $(17 \%)$, wood $(7 \%)$, tissue $(4 \%)$, rubber $(3 \%)$, ceramic $(2 \%)$, metal $(2 \%)$, glass $(1 \%)$, and other $(1 \%)$, as shown in Figure 2. "Other" items included candles, cigarettes, and foam. Solid waste was found in all samples throughout the year, with some areas being more affected than others.

When considering the two main types of solid waste (plastic and nylon), the one-way ANOVA test showed a temporal variation for plastic components $(\mathrm{F}=3.02 ; p=$ 0.03 ), with higher concentration during summer (Figure 3a). There was also a significant difference between fall and winter (Tukey test; $p=0.05$ ). On the other hand, nylon did not present significant variations between seasons $(\mathrm{F}=1.86 ; p=0.14)$ (Figure $3 \mathrm{~b})$.

The two-way ANOVA test showed a significant influence of the "area" factor on wastes stranding variation (Table 1). Variation in solid waste stranding according to season showed high standard deviations. The factors "season" and "season with area" presented no difference. But "area" had a significant influence on this variation. These differences indicate that the influence of the factors "area" and "season" are stronger when considered alone than together; it stresses the sampling areas location relevance over temporal changes. Data normality was verified with Shapiro-Wilk test $(\mathrm{W}=0.97$; $p=0.05)$ and Levene's test showed the homoscedasticity variation $(\mathrm{F}=0.59 ; p=0.87)$.

TABLE 1: Results from two-way ANOVA testing season and area influence on debris stranding at the Ratones mangrove, Santa Catarina Island (Brazil).

\begin{tabular}{lcc}
\hline Factors & F & $\boldsymbol{p}$ \\
\hline Season & 1.422 & 0.245 \\
Area & 5.750 & 0.001 \\
Season $v s$. Area & 0.587 & 0.803 \\
\hline
\end{tabular}

Figure 4 shows the fluctuation in amounts of solid waste strandings during seasons in each area. Areas 1 and 2 had higher amounts in summer, while Area 3 concentrated the stranding on fall. Area 4 had a small and growing variation from spring to winter. Area $2 \mathrm{had}$ fewer wastes and the fact that the confidence interval reaches negative amplitude reflects this very low amount on fall.

FIGURE 3: Average of solid waste stranded for plastic (a) and nylon (b) components throughout the seasons at the Ratones mangrove, Brazil. Boxes correspond to standard deviation, bars to confidence interval of $95 \%$ and black dots are outliers.

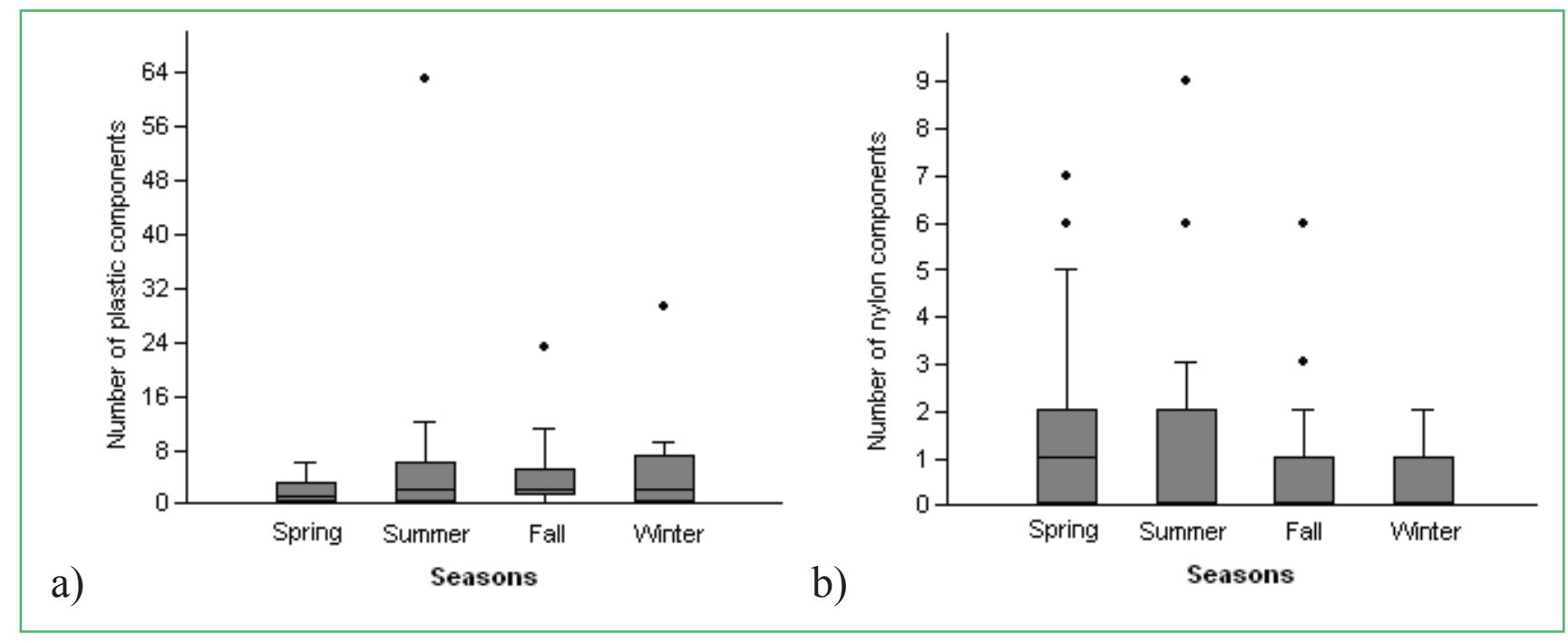


FIGURE 4: Fluctuation in solid waste stranding during seasons at four studied areas, Ratones mangrove (Brazil). Variations represent a $95 \%$ confidence interval.

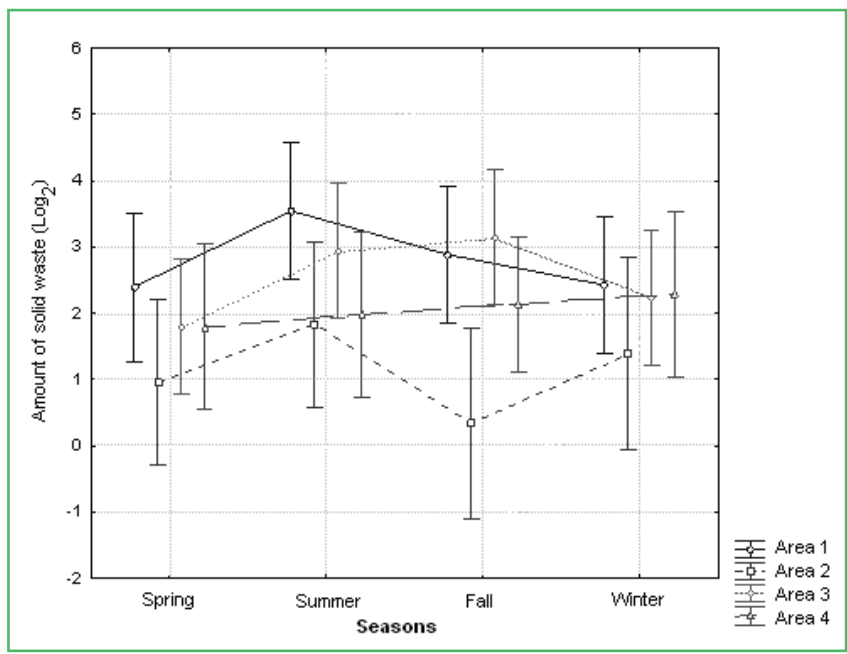

\section{Discussion}

Plastic and nylon items represented $80 \%$ of waste stranding, as other researches already found out in coastal environments (e.g. GREEN; WEBBER, 1996; DEBROT et al., 1999; DERRAIK, 2002; ARAÚJO; COSTA, 2004; SANTOS et al., 2005; IVAR DO SUL; COSTA, 2007; CORDEIRO; COSTA, 2010; MACHADO; FILLMANN, 2010; NETO; FONSECA, 2011; PORTZ et al., 2011; THIEL et al., 2011; TOURINHO; FILLMANN, 2011). Plastic products have become one of the major pollutants in the $21^{\text {th }}$ century (IVAR DO SUL; COSTA, 2007) because they are lightweight, strong, durable, cheap (WEHLE; COLEMAN, 1983; LAIST, 1987), and also have great versatility (DERRAIK, 2002). All these features led them to achieve commercial success and consumption increase in this "plastic age" (THOMPSON et al., 2009).

There were significant differences in temporal strandings only for plastic. On the other hand, nylon and the wastes total did not have significant temporal variation. These results could be explained by the waste sources dynamics. High values of plastic on summer could be related to population increase because of tourism and its connection to waste production. In the South Atlantic coast, several researches revealed tourist and fishing activities as major causes of marine pollution temporal accumulation (BARNES; MILNER, 2005; IVAR DO SUL; COSTA, 2007; MACHADO; FILLMANN, 2010; WIDMER; HENNEMANN, 2010; CARVALHO-SOUZA; TINÔCO, 2011; NETO; FONSECA, 2011; PORTZ et al., 2011; TOURINHO; FILMANN, 2011; VIEIRA et al., 2011).

Highest stranding in Areas 1 and 2 can be due to direct exposition to marine currents (VIEIRA et al., 2011). Area 2 had fewer residues, possibly because of Spartina alterniflora Loisel (Poaceae) effect (VIEIRA et al., 2011). Locations with Spartina alterniflora Loisel (Poaceae) dense edges in front seem to have less solid waste inside the mangrove forest, perhaps because this grass formation acts as a mesh barrier. Negative amplitude of confidence intervals in Area 2 may reflect low stranding in three seasons at this area. Vieira et al. (2011) found out the existence of spatial patterns in solid waste stranding distribution; however, this study reports the lack of a well established temporal variation.

During winter, windy and rainy weather in days previous to data collection may have contributed to light weight materials stranding, such as plastics. Wind and rain in days previous to data collection during summer and spring were also observed, thus contributing to solid waste presence in areas exposed to marine currents (Areas 1 and 2).

The main concern arising from this information is that solid waste stranding is occurring throughout the year in the whole region. Most wastes consist of synthetic products which are difficult to be degraded in the natural environment. Solid waste stranding can affect fish oviposition in grass (Spartina spp.) and pneumatophores. Human wastes cause significant threats to the marine ecosystem, representing danger not only to the biota, but also to social activities and people's health (OIGMAN-PSZCZOL; CREED, 2007; NETO; FONSECA, 2011).

Seasonal variation scenarios with regard to solid waste stranding need continued studies, with comparison between different years (e.g. NETO; FONSECA, 2011; PORTZ et al., 2011; SANTANA-NETO et al., 2011). We also emphasize the variations found in sites close to urbanized areas (Areas 1 and 3) and the transitional 
effect between ecosystems (Area 4), according to discussions of Vieira et al. (2011). Constant educational projects involving communities and tourists that use the region are mandatory, as well as actions towards impacts related to intense urbanization mitigation, such as goods consumption, with consequent waste production and illegal waste dump.

\section{Acknowledgements}

The authors thank Walter M. Widmer, Karla Z. Scherer, Mariana C. Hennemann, Carlos D. de O. Pires, Indionara L. Conceição, Mayana L. Leal, Sabrina Y. I. Minatelli and Thais G. R. da Silva for all great contributions to the field work. N.H. thanks CNPq for a research productivity fellowship.

\section{References}

ARAÚJO, M. C. B.; COSTA, M. F. Quali-quantitative analysis of the solid waste at Tamandare Bay, Pernambuco, Brazil. Tropical Oceanography, Recife, v. 32, n. 2, p. 159-170, 2004.

ARAÚJO, M. C. B.; COSTA, M. F. An analysis of the riverine contribution to the solid wastes contamination of an isolated beach at the Brazilian Northeast. Management of Environmental Quality: An International Journal, Cambridge, v. 18, n. 1, p. 6-12, 2007.

BARNES, D. K. A. Invasions by marine life on plastic debris Nature, London, v. 416, p. 808-809, 2002.

BARNES, D. K. A.; MILNER, P. Drifting plastic and its consequences for sessile organism dispersal in the Atlantic Ocean. Marine Biology, Kiel, v. 146, p. 815-825, 2005.

CARVALHO-SOUZA, G. F.; TINÔCO, M. S. Avaliação do lixo marinho em costões rochosos na Baía de Todos os Santos, Bahia, Brasil. Journal of Integrated Coastal Zone Managment, Faro, Itajaí e Coimbra, v. 11, n. 1, p. 135-143, 2011.

CHAPMAN, V. J. Ecosystems of the world. Oxford: Elsevier, 1977. 428 p.

COMCAP. Relatório de Gestão 2011. Florianópolis: Companhia de Melhoramentos da Capital, 2011. 51 p.

CORDEIRO, C. A. M. M.; COSTA, T. M. Evaluation of solid residues removed from a mangrove swamp in the São Vicente Estuary, SP, Brazil. Marine Pollution Bulletin, Amsterdam, v. 60, p. 1762-1767, 2010.

DEBROT, A. O.; TIEL, A. B.; BRADSHAW, J. E. Beach debris in Curacao. Marine Pollution Bulletin, Amsterdam, v. 38, p. 795801, 1999.

DERRAIK, J. G. B. The pollution of the marine environment by plastic debris: a review. Marine Pollution Bulletin, Amsterdam, v. 44, p. 842-852, 2002.
GREEN, S.; WEBBER, M. A survey of the solid waste pollution in Kingston Harbour mangroves, near Port Royal, Jamaica. Caribbean Marine Studies, Trindad, v. 5, p. 14-22, 1996.

HAMILTON, L. S.; SNEDAKER, S. M. Handbook for mangrove area manegement. 2 ed. Honolulu: East-West Center, 1984. 123 p. HINOJOSA, I. A.; PIZARRO, M.; RAMOS, M.; THIEL, M. Spatial and temporal distribution of floating kelp in the channels and fjords of southern Chile. Estuarine, Coastal and Shelf Science, New York, v. 87, p. 367-377, 2010.

HULBERT, S. H. Pseudoreplication and the design of ecological field experiments. Ecological Monographs, New York, v. 54, n. 2, p. 187-211, 1984.

IBGE. IBGE Censo 2010. 2010. Brasília: IBGE. Disponível em: $<$ http://www.censo2010.ibge.gov.br/dados_divulgados/index. php?uf $=42>$.

IVAR DO SUL, J. A.; COSTA, M. F. Marine debris review for Latin America and the Wider Caribbean Region: from the 1970 until now and where do we go from here? Marine Pollution Bulletin, Amsterdam, v. 54, p. 1087-1104, 2007.

LAIST, D. W. Overview of the biological effects of lost and discarded plastic debris in the marine environment. Marine Pollution Bulletin, Amsterdam, v. 18, p. 319-326, 1987.

LAL, P. Economic valuation of mangroves and decision-making in the Pacific. Ocean \& Coastal Management, Augustinusga, v. 46, p. 823-844, 2003.

LUGO, A. E.; SNEDAKER, S. C. The ecology of mangroves. Annual Review of Ecology, Evolution and Systematics, Palo Alto, v. 5, p. 39-64, 1974.

MACHADO, A. A.; FILLMANN, G. Estudo da contaminação por resíduos sólidos na ilha do Arvoredo, Reserva Biológica Marinha do Arvoredo - SC, Brasil. Journal of Integrated Coastal Zone Management, Faro, Itajaí e Coimbra, v. 10, n. 3, p. 381-393, 2010. MARTINEZ, E.; MAAMAATUAIAHUTAPU, K.; TAILLANDIER, V. Floating marine debris surface drift: convergence and accumulation toward the South Pacific subtropical gyre. Marine Pollution Bulletin, Amsterdam, v. 58, p. 1347-1355, 2009.

NAGELKERKEN, I.; BLABER, S. J. M.; BOUILLON, S.; GREEN, P.; HAYWOOD, M.; KIRTON, L. G.; MEYNECKE, J. O.; PAWLIK, J.; PENROSE, H. M.; SASEKUMAR, A.; SOMERFIELD, P. J. The habitat function of mangroves for terrestrial and marine fauna: A review. Aquatic Botany, Gainesville, v. 89, p. 155-185, 2008

NETO, J. A. B.; FONSECA, E. M. Variação sazonal, espacial e composicional de lixo ao longo das praias da margem oriental da Baía de Guanabara (Rio de Janeiro) no período de 1999-2008. Journal of Integrated Coastal Zone Management, Faro, Itajaí e Coimbra, v. 11, n. 1, p. 31-39, 2011.

OIGMAN-PSZCZOL, S. S.; CREED, J. C. Quantification and classification of marine litter on beaches along Armação dos Búzios, Rio de Janeiro, Brazil. Journal of Coastal Research, Fort Lauderdale, v. 23, n. 2, p. 421-428, 2007.

PARIDA, A. K.; JHA, B. Salt tolerance mechanisms in mangroves: A review. Trees - Structure and Function, Vancouver, v. 24, n. 2 , p. 199-217, 2010.

POLIDORO, B. A.; CARPENTER, K. E.; COLLINS, L.; DUKE, N. C.; ELLISON, A. M.; ELLISON, J. C.; FARNSWORTH, E. J.; FERNANDO, E. S.; KATHIRESAN, K.; KOEDAM, N. E.; 
LIVINGSTONE, S. R.; MIYAGI, T.; MOORE, G. E.; NAM, V. N.; ONG, J. E.; PRIMAVERA, J.H.; SALMO, S. G.; SANCIANGCO, J. C.; SUKARDJO, S.; WANG, Y.; YONG, J. W. H. The loss of species: mangrove extinction risk and geographic areas of global concern. PLoS ONE, Cambridge, v. 5, n. 4, p. 1-10, 2010.

PORTZ, L.; MANZOLLI, R. P.; IVAR DO SUL, J. A. Marine debris on Rio Grande do Sul north coast, Brazil: spatial and temporal patterns. Journal of Integrated Coastal Zone Management, Faro, Itajaí e Coimbra, v. 11, n. 1, p. 41-48, 2011.

POSSATTO, F. E.; BARLETTA, M.; COSTA, M. F.; IVAR DO SUL, J. A.; DANTAS, D. V. Plastic debris ingestion by marine catfish: an unexpected fisheries impact. Marine Pollution Bulletin, Amsterdam, v. 62, p. 1098-1102, 2011.

PROVENCHER, J. F.; GASTON, A. J.; MALLORY, M. L.; O'HARA, P. D.; GILCHRIST, H. G. Ingested plastic in a diving seabird, the thick-billed murre (Uria lomvia), in the eastern Canadian Arctic. Marine Pollution Bulletin, Amsterdam, v. 60, p. 1406-1411, 2010.

SANTANA-NETO, S. P.; SILVA, I. R.; LIVRAMENTO, F. C. Padrões de deposição e origens do lixo marinho em praias da ilha de Itaparica - Bahia. In: SIMPÓSIO BRASILEIRO DE OCEANOGRAFIA, V, 2011, Santos. Anais... Santos: IOUSP, 2011. Vol. 1. p. 1-5.

SANTOS, I. R.; FRIEDRICH, A. C.; BARRETO, F. P. Overseas garbage pollution on beaches of Northeast Brazil. Marine Pollution Bulletin, Amsterdam, v. 50, p. 778-786, 2005.

SCHAEFFER-NOVELLI, Y.; CINTRÓN, G. Guia para estudo de áreas de manguezal: estrutura, função e flora. 2 ed. São Paulo: Editora Caribbean Ecological Research, 1986. 431 p.

SOUZA, G. D.; CARVALHO, C. B. N.; DAVID, C. J. Comparison of solid residues accumulated in the mangroves of Baixada Santista estuaries. In: Brazilian Symposium on Oceanography, III, 2008, São Paulo. Annals... São Paulo: SBO, 2008. p. 607-613.

SPALDING, M.; BLASCO, F.; FIELD, C. World Mangrove Atlas. Okinawa: ISME, 178p. 1997.

STATSOFT INC. Statistica 7.0 ${ }^{\circledR}$ 2004. Oklahoma: Statsoft. Available online at $<$ http://www.statsoft.com $>$.

THIEL, M.; HINOJOSA, I. A.; JOSHKO, T.; GUTOW, L. Spatio- temporal distribution of floating objects in the German Bight (North Sea). Journal of Sea Research, Den Burg, v. 65, p. 368-379, 2011. THOMPSON, R. C.; SWAN, S. H.; MOORE, C. J.; VON SAAL, F. S. Our plastic age. Philosophical Transections of the Royal Society B: Biological Sciences, London, v. 364, p. 1973-1976, 2009.

TOMLINSON, P. B. The botany of mangroves. 2 reimp. Cambridge, New York, New Rochelle, Melbourne, Sydney: Cambridge University Press, 1988. 433 p.

TOURINHO, P. S.; FILMANN, G. Temporal trend of litter contamination at Cassino beach, Southern Brazil. Journal of Integrated Coastal Zone Management, Faro, Itajaí e Coimbra, v. 11, n. 1, p. 97-102, 2011.

TOURINHO, P. S.; IVAR DO SUL, J. A.; FILLMANN, G. Is marine debris ingestion still a problem for the coastal marine biota of southern Brazil? Marine Pollution Bulletin, Amsterdam, v. 60, p. 396-401, 2010.

VIEIRA, B. P.; DIAS, D.; HANAZAKI, N. Homogeneidade de encalhe de resíduos sólidos em um manguezal da Ilha de Santa Catarina, Brasil. Journal of Integrated Coastal Zone Management, Faro, Itajaí e Coimbra, v. 11, n. 1, p. 21-30, 2011.

VLIETSTRA, L. S.; PARGA, J. A. Long-term changes in the type, but not amount, of ingested plastic particles in short-tailed shearwaters in the southeastern Bering Sea. Marine Pollution Bulletin, Amsterdam, v. 44, p. 945-955, 2002.

WEHLE, D. H. S.; COLEMAN, F. C. Plastics at sea. Natural History, New York, v. 2, p. 20-24, 1983.

WIDMER, W. M.; HENNEMANN, M. C. Marine debris in the Island of Santa Catarina, South Brazil: spatial patterns, composition, and biological aspects. Journal of Coastal Research, Fort Lauderdale, v. 26, n. 6, p. 993-1000, 2010.

ZAR, J. H. Biostatistical analysis. 4 ed. New Jersey: Prentice-Hall Inc., 1999. 663 p. 